\title{
Analysis of the preparatory phase of a construction investment in the area covered by revitalization
}

https://doi.org/10.1515/eng-2019-0052

Received March 22, 2019; accepted June 12, 2019

\begin{abstract}
The issue of preparing a construction project, especially in the area covered by revitalisation, requires a comprehensive approach and, above all, a multifaceted analysis of the conditions during the programming and planning of the investment. Currently, the majority of investments carried out in the areas covered by the Revitalisation Programme are carried out by public entities, which results from a number of possible risks of failure of the project.

The article presents possible scenarios of administrative proceedings related to planning the implementation of an investment located in the areas covered by the Revitalization Program based on the requirements of legal regulations. A list and the amount of co-financing for the investments carried out so far located in revitalised areas were also presented. Finally, an exemplary SWOT matrix for a private sector investor was proposed, which may support him in the decision to undertake a project in the area covered by the Revitalisation Programme.
\end{abstract}

Keywords: revitalization, preparation phase, historical substance, endowment, risk

\section{Introduction}

The construction of a new building as well as the renovation, refurbishment and/or reconstruction of an existing building constitutes a construction project. It takes time and costs to complete, so it can be described as an invest-

\footnotetext{
*Corresponding Author: Aleksandra Radziejowska: AGH University of Science and Technology in Cracow, Department of Geomechanics, Civil Engineering and Geotechnics, E-mail: aradziej@agh.edu.pl

Joanna Sagan: AGH University of Science and Technology in Cracow, Department of Geomechanics, Civil Engineering and Geotechnics
}

ment and construction process, consisting of phases that include many stages and tasks. The preparatory phase of a construction project consists of activities preceding the execution of construction works, including preliminary studies with examination of risks to the investment, planning and design processes, and administrative proceedings [1].

Implementation of the investment in the area covered by the revitalisation is burdened with a complex administrative process and additional restrictions and requirements in terms of design. It also has a specific set of risks that may occur, including in the preparatory phase. Despite the difficulties that occur throughout the entire investment cycle, the implementation of the project brings benefits for both the investor and the local community.

The article presents the characteristics of the revitalisation process (chapter 2), the process of administrative proceedings related to the implementation of the investment in the revitalised area (chapter 3) was also discussed. The description was complemented by a graphical interpretation of the process, with the use of BPMN notation (Business Process Model and Notation). Due to the prevalence of investment grants in this area, the source and amount of investment grants were analysed (Chapter 4). The summary and conclusions were supplemented by the SWOT matrix for private sector investment in real estate covered by the revitalisation programme (Chapter 5).

\section{Related works}

The term revitalisation (restoring life, resuscitation) is a particularly capacious concept, which creates opportunities to include various activities leading to spatial and functional changes in urban areas (and beyond), which will contribute to economic, social and cultural development, to spatial order, aesthetics and functionality of these areas [2-4].

It should be emphasized here that many publications attach great importance to social, cultural, historical, 
functional, financial and even health aspects of revitalisation $[3,5-8]$.

It is often stressed that this process is initiated in situations where market forces do not bring the expected results. Then public intervention is needed. Foreign experience proves that the investors in revitalisation processes may be private sector companies, including those undertaking cooperation with the public sector [9].

From the construction point of view, the most frequently mentioned revitalization activities include the reconstruction or rebuilding of currently devastated, and in the past functioning urbanized spaces, including buildings. Planning and execution of construction investments in the area of revitalization has several advantages, of which the main can be identified as an attractive location, prestige of the building itself (including cultural value) and the possibility of obtaining co-financing for the implementation of the project.

\section{Administrative proceedings prior to the purchase of real estate}

On 18 November 2015, the Act on revitalisation came into force. It defines the concept of revitalization as: the process of recovering degraded areas from the state of crisis, carried out in a comprehensive manner, through integrated actions for the local community, space and economy, territorially concentrated, carried out by stakeholders of revitalisation on the basis of the municipal revitalisation programme [10].

For a given area covered by revitalisation, a long-term Revitalisation Programme (RP) is created. The development and coordination of such a programme is the responsibility of local government units or (on request) external institutions.

Planning investments in the revitalised area is connected with the necessity to adjust the investment objectives to the assumptions of the revitalisation programme. On the other hand, the very process of purchasing real estate located in the RP area is connected with the implementation of a complicated procedure both on the part of the contracting authority and the local authority (Fig. 1), thus the time of purchase is repeatedly prolonged.

The first step on the way of purchasing a building or a complex of buildings is to check the resolutions of the $\mathrm{Mu}$ nicipal Council concerning the areas covered by RP. The status of the property should be included in the local law. If the object of interest to the investor is not covered by the Revitalisation Plan, the proceedings concerning the purchase of real estate, and then the planning of works is car- ried out in accordance with the procedures included in the provisions of the Construction Law.

If the site is located in a RP area, a detailed description of the site should be read in the first stage. At the beginning, it should be checked whether within 2 years from the date of entry into force of the resolution on designating the degraded area and the area of revitalization, the resolution on the establishment of a Special Regeneration Zone (SRZ) has not entered into force. If SRZ was not established, within 2 years after the acquisition of a given $\mathrm{RP}$ area, the pre-emption right established by the municipality and the prohibition of issuing decisions on development conditions cease to apply. A stakeholder may participate in the standard tendering procedure.

A more difficult situation arises when the commune has established a Special Revitalisation Zone. In this case, the commune (by virtue of law) will have the right of first refusal (decision of the mayor or president) for up to 10 years. However, a stakeholder may enter into a conditional sales agreement, which should be notified to the head of the commune, mayor or president, who, within one month of receiving notification of the content of the agreement, may submit a statement of the exercise of the pre-emptive right.

During the purchase of a property, a stakeholder may encounter one more restriction, which may occur during the purchase of the property. The municipal council may introduce a ban on issuing a decision on development conditions or a ban on certain changes in the manner of land development requiring such a decision. This difficulty, depending on the investor's plans, may lead to the investor's withdrawal from the willingness to purchase real estate or to the inclusion of these difficulties in future renovation plans.

\section{Co-financing of investments from the Revitalisation Programme}

As part of the construction investment in the areas covered by the revitalisation plan, it is possible to obtain cofinancing. Owners of properties located in the Special Revitalisation Zone may receive a grant from the commune for construction works consisting in renovation or reconstruction, as well as conservation or restoration works. The communal subsidy may amount to up to $50 \%$ of the necessary outlays. Applying for funds requires the preparation of appropriate documentation prepared in the form of the so-called Revitalisation Plan (RPL). The PRL documentation is presents a plan of preservation of the historic sub- 


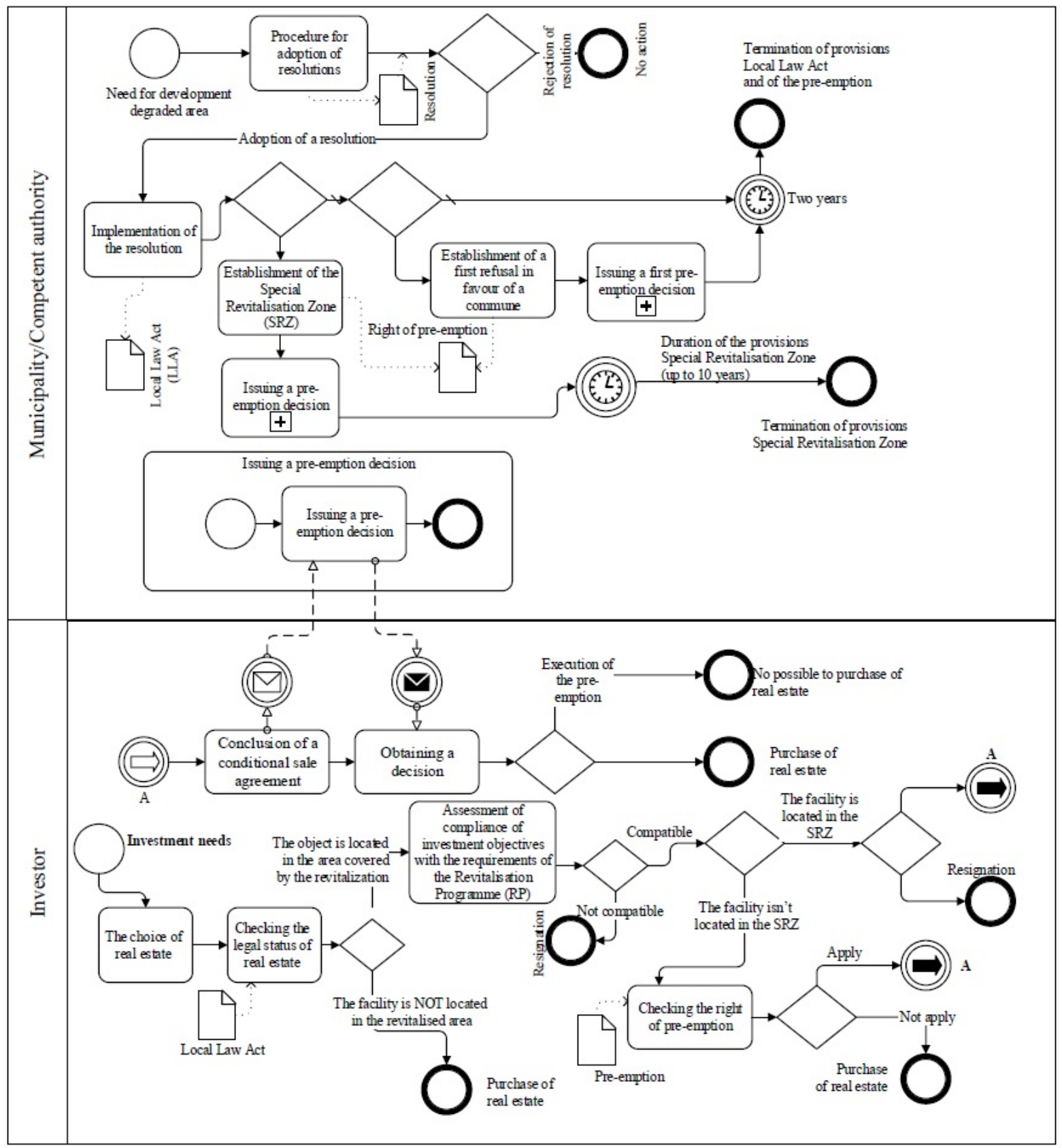

Figure 1: Acquisition of real estate in the area covered by revitalisation (own elaboration based on [10]

stance in the form of fragments of the structure, elements of equipment and decoration, as well as historic devices of technology. The Revitalisation Plan is a necessary document to receive co-financing from the institutions of the Integrated Regional Development Operational Programme (IRDOP), which in turn is financed from the European Regional Development Fund (ERDF) and the European Social Fund (ESF).

Table 1 presents examples of investment grants from European funds whose stakeholders were not municipal- ities but foundations, housing cooperatives and private companies.

In order to determine the amount of EU funds for investments carried out in the areas covered by RP, the authors presented data on the scale of co-financing of projects already implemented (or in the course of implementation) in Poland, using a histogram and the so-called box-plot diagram, which allow to illustrate the central tendency, dispersion and asymmetry of the distribution of the results of the examined sample (Fig. 2, Fig. 3). 
Table 1: Examples of amounts of co-financing for investments in revitalized areas from European funds (data collected from [11])

\begin{tabular}{lcc}
\hline Object & $\begin{array}{c}\text { Value of } \\
\text { the project } \\
\text { [PLN] }\end{array}$ & $\begin{array}{c}\text { Co-financing } \\
\text { from European } \\
\text { funds [PLN] }\end{array}$ \\
\hline $\begin{array}{c}\text { Construction of the Tadeusz Kantor Museum and the headquarters of } \\
\text { the Tadeusz Kantor Art Documentation Centre - CRICOTEKA }\end{array}$ & 49204070 & 33232281 \\
\hline $\begin{array}{c}\text { Revitalization, conservation and adaptation of the palace-park complex } \\
\text { in Gorzanów in order to create cultural institutions there - reconstruction }\end{array}$ & 7805899 & 6578064 \\
\hline $\begin{array}{c}\text { Revitalization of a historic tenement house at 7 Warmińska Street in } \\
\text { Olsztyn }\end{array}$ & 1495167 & 1024360 \\
\hline $\begin{array}{c}\text { Restoration of the gate passage and the courtyard at the annexe of } \\
\text { tenement houses at the Old Town Square 32/33/34 in Toruń - In the } \\
\text { shade of Gothic }\end{array}$ & 792994 & 306362 \\
\hline $\begin{array}{c}\text { Complex renovation in a tenement house located at 20 Przedzamcze } \\
\text { Street }\end{array}$ & 596076 & 250000 \\
\hline $\begin{array}{c}\text { Adaptation of a tenement house located in Bydgoszcz at 5 Mostowa } \\
\text { Street, located in the area listed in the register of monuments for } \\
\text { economic and social (public utility) purposes }\end{array}$ & 425213 \\
\hline
\end{tabular}

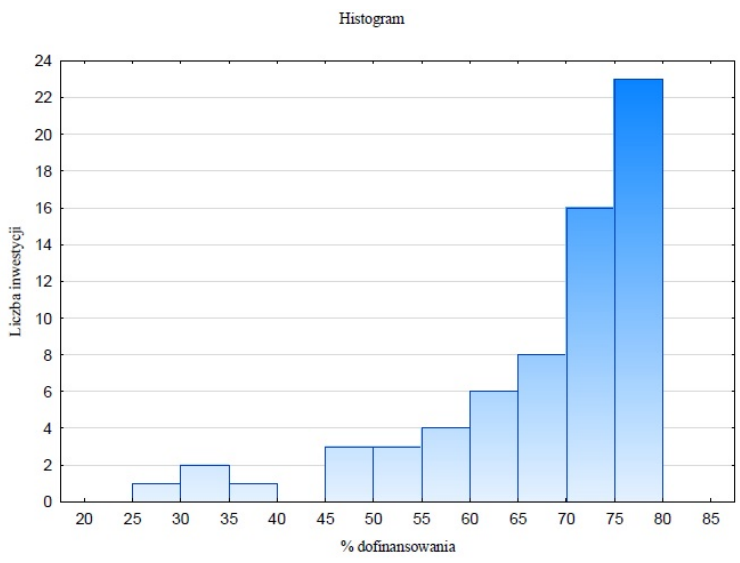

Figure 2: Overview of the percentage of co-financing of the costs of investments covered by the Revitalisation Programme (own elaboration)

The charts show that in the majority of the implemented investments the co-financing reached over $65 \%$ (the average was $67.27 \%$, while the median - $72.20 \%$ ). Only a few of the analysed investments obtained co-financing below $50 \%$ of the costs. These data show that obtaining co-financing is undoubtedly a great advantage and gives a great chance for the implementation of investments with a significant profit.

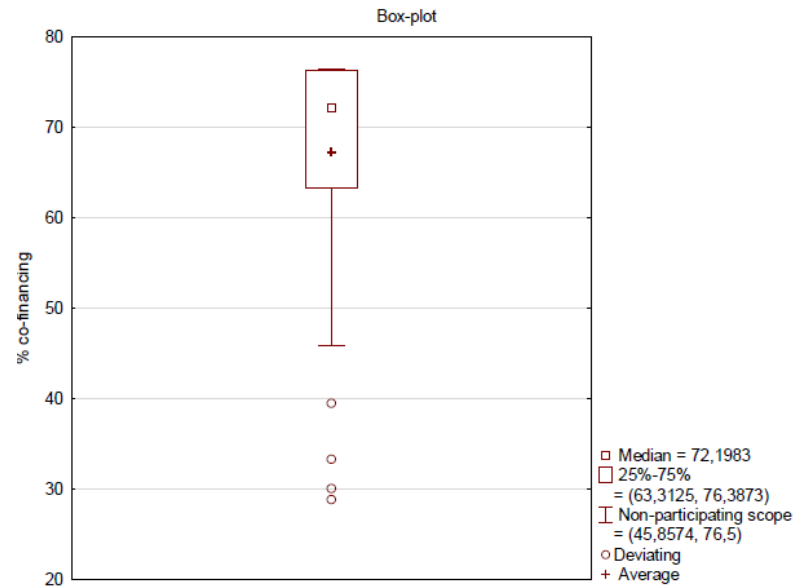

Figure 3: Chart of a frame - a moustache showing the average and median of co-financing of projects covered by RP (own elaboration)

\section{Summary}

Following the example of Western European countries, the revitalisation process must be financially supported not only by local authorities, first and foremost local authorities, but also by regional, national, local and, which is particularly important, private entities (investors). As part of the summary of strengths and weaknesses, opportunities and threats to private investment in the area of revitalisation, the SWOT matrix is presented below (Fig. 4).

The combination of strengths and weaknesses as well as opportunities and threats occurring during investments 


\begin{tabular}{|c|c|}
\hline STRENGHTS & WEAKNESSES \\
\hline 1. Prestige of investments & 1. Lack of specialists to carry out an unusual and difficult to carry out the investment \\
\hline 2. Attractive location & 2. Problems with compiling documentation \\
\hline 3. Gaining experience while running an & 3. Difficulties with the preparation of the Revitalisation Plan \\
\hline untypical project & 4. Problems with maintaining the consistency of the PR concept with the city's plans \\
\hline 4. High profit (when obtaining co-financing) & 5. Restrictions related to the establishment of a Special Revitalisation Zone \\
\hline 5. High interest of potential buyers & $\begin{array}{l}\text { 6. Necessity of large financial outlays related to the conservation of the historical } \\
\text { substance } \\
\text { 7. Difficulties in keeping to the time and costs of the implemented investment } \\
\text { 8. Difficulties with investments in densely built-up areas (e.g. limited construction } \\
\text { site, difficult access, etc.) }\end{array}$ \\
\hline OPPORTUNITIES & THREATS \\
\hline $\begin{array}{l}\text { 1. Possibility of large co-financing from EU } \\
\text { funds } \\
\text { 2. Winning awards for the implementation of } \\
\text { a prestigious investment } \\
\text { 3. Getting great specialists in the industry } \\
\text { 4. Possibilities for further projects of this } \\
\text { type }\end{array}$ & $\begin{array}{l}\text { 1. Strong competition } \\
\text { 2. Problems with obtaining permits from the Monument Conservator } \\
\text { 3. Lengthy procedures for obtaining the necessary permits } \\
\text { 4. Restrictions on the implementation of investments due to existing programmes in } \\
\text { this area } \\
\text { 5. Amendments to the development plan during the preparatory phase } \\
\text { 6. Lack of co-financing from EU funds } \\
\text { 7. Unfavourable changes in legal regulations }\end{array}$ \\
\hline
\end{tabular}

Figure 4: Example of a SWOT matrix for a potential investor planning a construction project in the area covered by the Revitalisation Programme (own elaboration)

carried out in revitalised areas may make it easier for a private sector investor to make a decision concerning the undertaking of such an construction project. A great advantage and a chance of greater interest of the private sector in this area seems to be the possibility of large co-financing of this type of investments from EU funds.

Effective reasoning based on the analysis of already completed investments in revitalised areas can be based on algorithms such as Context-Aware Bandits [12]. This algorithm makes it possible to find the best or most profitable action. The mechanism of the algorithm is a hypothetical experiment in which several slot machines ('onearmed bandits') provide potentially different expected profits (based on previous experience). Thanks to such inference, it can be found the most profitable path of proceedings.

Currently, however, it is rare to invest in a revitalized area by the private sector. Investors' reluctance results from the excessive formalisation of administrative proceedings and the multitude of risks associated with the implementation of projects in this area, which are already visible at the stage of initiation of the project. The need to adapt investment objectives to revitalisation programmes is a source of investment risk, both at the stage of real estate purchase and in further administrative proceedings related to the issue of construction work permits. However, some opportunities should be seen in the possibility of obtaining funding for the implementation of projects, the amount of which represents on average over $67 \%$ of the project value.

\section{References}

[1] Collective work edited by Tadeusz Kasprowicz, Inżynieria predsięwzięćc budowlanych. Rekomendowane metody i techniki. Warszawa, 2015.

[2] S. Kaczmarek, Rewitalizacja terenów poprzemysłowych: nowy wymiar $w$ rozwoju miast. Wydaw. Uniwersytetu Łódzkiego, 2001.

[3] J. J. Parysek, "Rewitalizacja jako problem i zadanie własne polskich samorządów lokalnych,” Rozw. Reg. i Polityka Reg., vol. 33, pp. 17-35, 2016.

[4] J. Parysek, "Development of Polish towns and cities and factors affecting this process at the turn of the century," Geogr. Pol., vol. 78, pp. 99-115, 2005.

[5] A. Adair, J. Berry, S. McGreal, B. Deddis, and S. Hirst, "The financing of urban regeneration," Land use policy, vol. 17, no. 2, pp. 147-156, 2000.

[6] A. Lubecka, "Rewitalizacja/gentryfikacja jako element zmieniający semantykę miasta," $O$ budowie Metod rewitalizacji $w$ Polsce-aspekty wybrane, p. 157, 2010.

[7] C. Couch, O. Sykes, and W. Börstinghaus, "Thirty years of urban regeneration in Britain, Germany and France: The importance of context and path dependency," Prog. Plann., vol. 75, no. 1, pp. 1-52, 2011.

[8] A. Geppert, "Planning systems facing heritage issues in Europe: from protection to management, in the plural interpretations of the values of the past," 2015.

[9] A. Adair, J. Berry, S. McGreal, B. Deddis, and S. Hirst, "Evaluation of Investor Behaviour in Urban Regeneration," Urban Stud., vol. 36, no. 12, pp. 2031-2045, 1999.

[10] U. Dz.U. 2015 poz. 1777, “Ustawa z dnia 9 października o rewitalizacji Dz.U. 2015 poz. 1777," Minist. Wtaściwy ds Budownictwa Lokal. Plan. i Zagospod. Przestrz. oraz Mieszk., pp. 1-23, 2018.

[11] “Mapa dotacji UE.” Online. Available: https://mapadotacji.gov. $\mathrm{pl} /$. [Accessed: 11-Jun-2019].

[12] S. Li, A. Karatzoglou, and C. Gentile, "Collaborative Filtering Bandits," 2015. 